\title{
MENSAJE PRESIDENTE ALOP
}

Dr. Francisco José Hernández Restrepo

Apreciados Colegas:

Para la Asociación Latinoamericana de Odontopediatria ALOP es un gran orgullo poder entregar a los odontólogos latinoamericanos nuestra revista de investigación en temas de odontopediatría, escrita y editada en español y portugués, nuestros idiomas, con excelentes artículos creados y desarrollados por nuestros científicos latinoamericanos. Nuestro objetivo es dar un espacio para que cada país difunda sus investigaciones y que pueda ser leída por todos los profesionales de la salud. Dentro del plan estratégico de crecimiento de ALOP, se encuentra el desarrollo de planes de investi-

gación de la problemática de salud bucal de nuestros niños latinoamericanos, el compromiso social de los odontopediatras, y la difusión de nuestras investigaciones.

A nombre de la Asociación Latinoamericana de Odontopediatría agradezco a todas las sociedades que nos integran, a sus miembros: los odontólogos pediatras de Latinoamérica y a todos nuestros leales colaboradores en todas las aéreas por su desinteresado y eficiente trabajo para que ALOP pueda seguir en el camino de lograr un mejor mundo para nuestros niños desde nuestro campo.

Agradecemos a nuestros editores que creyeron en este sueño y trabajaron muy duro para llevar a cabo y volverlo una realidad convertida en una revista digital no de un país, si no de una región y en dos idiomas. Gracias a nuestro comité editorial, revisores y sobre todo a los investigadores que nos apoyan desinteresadamente sabiendo que en este momento nuestra revista por ser nueva todavía no se encuentra indizada, es nuestro proyecto lograrlo en un corto plazo.

Esperamos que la disfruten y esperen con ansias nuestra próxima edición.

\section{MENSAGEM PRESIDENTE ALOP}

\section{Dr. Francisco José Hernández Restrepo}

Caros colegas:

A Associação Latino-Americana de Odontopediatria ALOP tem muito orgulho de entregar a nossa revista de pesquisa de tópicos odontopediatria, escrito e editado em Espanhol e Português, a nossa língua, com excelentes artigos criados e desenvolvidos por nossos cientistas da América Latina. Nosso objetivo é proporcionar um espaço para cada país para divulgar suas pesquisas e pode ser lido por todos os profissionais de saúde. Dentro do plano estratégico de crescimento da ALOP, é o desenvolvimento de agendas de investigação do problema da saúde bucal de nossas crianças na América Latina, o compromisso social das odontopediatras e divulgação da nossa pesquisa.

Em nome da Associação Latino-americana de Odontopediatria agradecer a todas as instituições científicas que integram, a seus membros: odontopediatras na América Latina e todos os nossos parceiros leais em todas as transportadoras por seu trabalho abnegado e eficiente para ALOP pode continuar no caminho um mundo melhor para nossas crianças de nossa região.

Agradecemos aos nossos editores que acreditaram neste sonho e trabalhou muito para sair e torná-lo realidade se transformou em uma revista não um país, se não uma região em duas línguas. Graças ao nosso conselho editorial, revisores e, especialmente, para os pesquisadores que generosamente nos apoiar neste momento sabendo que a nossa revista por ser novo ainda não está indexado, ele é o nosso projeto para alcançar a curto prazo.

Esperamos que goste e aguardamos a próxima edição. 